\title{
Diversity in Tannin and Fiber Content in Areca Nut (Areca catechu) Samples of Karnataka, India
}

\author{
B.R. Gurumurthy* \\ Department of Crop Physiology, University of Agricultural and Horticultural sciences, \\ Shivamogga-577225, Karnataka, India \\ *Corresponding author
}

\begin{tabular}{|l|}
\hline Ke y w o r d s \\
$\begin{array}{l}\text { Tannin, Titrimetric } \\
\text { method, Fiber, } \\
\text { Areca nut, Fibrotron }\end{array}$ \\
\hline Article Info \\
\hline $\begin{array}{l}\text { Accepted: } \\
\text { 20 December } 2017 \\
\text { Available Online: } \\
\text { 10 January 2018 }\end{array}$ \\
\hline
\end{tabular}

\section{Introduction}

Tannins are water-soluble Polyphenols widely distributed in many plant species and present in many plant foods. Tannins occur normally in the roots, wood, bark, leaves, and fruit of many plants, where they play a role in protection from predation, and perhaps also as pesticides, and in plant growth regulation. The

\begin{abstract}
Tannins are water soluble Polyphenols, known as proanthocyanidins possessing useful properties such as antioxidant, anti- apoptosis, and anti-aging, anti-carcinogenic, antiinflammatory as well as anti-atherosclerosis and cardiovascular protection. In this study tannin content in various arecanut samples was assessed by titrimetric method. Arecanut samples were collected from Shimoga, Davanagere, Chikkamagalur, Chitradurga, Dakshina kannada (DK) and Udupi districts of Karnataka, India. The dried powdered arecanut samples were used for the estimation of Tannin content. Tannin contents in different districts ranged from $1.13 \%$ to $3.39 \%$. The Concentration of Tannin varied significantly among hoblies and districts of Karnataka state. Crude fiber in tender areca nuts is very low (1-2\%). With maturity and ripening, fiber forms continuously and the rate of formation increases from the mature green stage. Fiber is responsible for the hardness of the nuts, which takes place after the mature- green stage, when nuts are taken to prepare the cut and boiled types known as kalipak. In Shimoga district, Sagara and Hosanagara taluks had high fiber content (65.22 and 62.36 \%) and less was seen in Bhadravathi taluk $(36.33 \%)$. In Tarikere and N R pura taluks of Chikkamagalur district, high amount of fiber contents of 57.51 and $56.19 \%$ was recorded, and it was less in Mudigere taluk (28.02\%). 52.80 and 52.78 per cent of fiber were observed in Harihara and Jagalur taluk of Davanagere district. There was no significant difference in fiber content of Chitradurga district. The diversity in tannin and fiber content may be due to variability in processing technique, climate, varieties, water stress, soil conditions etc.

A B S T R A C T
\end{abstract}

reactivity of condensed tannins with molecules of biological significance such as proteins, metal ions and polysaccharides has important nutritional and physiological consequences, and hence the determination of the content of tannin in plant material is important. Tannin exhibit many biologically significant functions such as protection against oxidative stress, and degenerative diseases 
(Atanassova et al., 2009). Tannins are a broad class of compounds that is present in tea, red wine, cocoa, areca nuts, chocolates, coffee, some herbal preparations, grapes and certain fruits like blackberries and cranberries.

Tannin of areca nut is being used for dyeing clothes, as adhesives in plywood manufacture and for tanning standard for home use in South East Asia and the Pacific Ocean countries. The tannins are obtained as byproduct while preparing immature betel nuts for chewing.

Fiber is very important component in agricultural crops. It helps in easy digestion of food materials and avoids constipation. The crops have different amount of fiber and hence, it is very much essential to find out fiber content in these crops. Fiber is formed at a fast rate from the middle stages bringing down the concentration of the constituent found in large concentrations from the early stages. Crude fiber in a tender areca nut is very low being 1 - 2 per cent.

With maturity and ripening, fiber is formed continuously and the rate of formation increases from the mature green stage. Fiber is responsible for the hardness of the nuts. The fiber content is index of the quality of areca nut. As the moisture content of nut decreases, buildup of crude fiber is noticed.

\section{Materials and Methods}

Arecanut samples were collected from different districts of Karnataka (shivamogga, Davangere, Chikkamagalur, Chitradurga, Udupi, and Dakshina kannada) and stored in airtight polybags in a refrigerator until they were used for laboratory analysis. The difference between two titration represents the indigo carmine solution required to neutralize the tannin. Each $\mathrm{ml}$ of $0.1 \mathrm{~N} \mathrm{KMnO}_{4}$ is equivalent to 0.004157 of tannin.

\section{Reagents}

\section{Indigo carmine solution}

$1.5 \mathrm{~g}$ of indigo carmine was dissolved in 1000 $\mathrm{ml}$ of distilled water containing $50 \mathrm{ml}$ of sulphuric acid.

\section{$0.1 \mathrm{NMnO}_{4}$ solution}

$3.16 \mathrm{~g}$ of $\mathrm{KMnO} 4$ was dissolved in $1000 \mathrm{ml}$ of distilled water, heat on a water bath for one hour, store for 2 days and filter through Whatman No. 1 filter paper.

\section{Calculation}

The Tannin content ( $\mathrm{T} \%$ ) in the sample is calculated as follows:

$(\mathrm{A}-\mathrm{B}) \times 0.004157 \times 100 \times \mathrm{N} / \mathrm{W} \times 0.1$

$\mathrm{A}=$ volume of $0.1 \mathrm{~N} \mathrm{KMnO}_{4}$ consumed in titration (Test)

$\mathrm{B}=$ volume of $0.1 \mathrm{~N} \mathrm{KMnO}_{4}$ consumed in titration (Blank)

$\mathrm{W}=$ weight of material taken in $\mathrm{g}$

$\mathrm{N}=$ normality of potassium permanganate

Determination of tannin in areca by titrimetric method

$50 \mathrm{ml}$ of water was added to $1.0 \mathrm{~g}$ powdered areca sample, shake for 15 minutes, filter through Whatman No. 1 filter paper. Incubate at room temperature for 2 hours and again filter.

Make up volume to $100 \mathrm{ml}$ and add $1.0 \mathrm{ml}$ of Indigo carmine solution, shake well and titrate against $0.1 \mathrm{~N} \mathrm{KMnO}_{4}$ solution until end point of golden yellow colour is seen. Find out the volume of $0.1 \mathrm{~N} \mathrm{KMno}_{4}$ consumed in titration with and without sample. 


\section{Estimation of Areca fiber by Fibertron equipment}

Accurately weigh $2.0 \mathrm{~g}$ powdered areca sample and transfer into a round bottom flask/ crucible. Add $100 \mathrm{ml}$ of $1.25 \% \mathrm{H}_{2} \mathrm{SO}_{4}$ and boil at $400^{\circ} \mathrm{C}$ for 10 minutes and at $350^{\circ} \mathrm{C}$ for 30 minutes. Wash the sample with water. Add $100 \mathrm{ml}$ of $1.25 \% \mathrm{NaOH}$ and boil for 10 minutes and at $350^{\circ} \mathrm{C}$ for 30 minutes, wash with water and take out crucibles from the equipment. Now add $10 \mathrm{ml}$ of ethanol and dry for 2 hours at $105^{\circ} \mathrm{C}$, cool and record the weight of residue $\left(\mathrm{W}_{2}\right)$. Place the residue in a muffle furnace and obtain ash at $500^{\circ} \mathrm{C}$, Note down weight of ash $\left(\mathrm{W}_{3}\right)$.

\section{Results and Discussion}

\section{Tannin content $(\%)$ in areca nut}

The amount of tannin in areca nut samples collected from different taluks of Karnataka is presented in table 1. Almost all areca nut samples contained tannin in the range of 1.13 - $3.39 \%$. In Shimoga district the large quantity of tannin was found in Thirthahalli (3.23\%) and Sorab taluks (3.15\%) followed by Bhadravathi $(3.04 \%)$ and Shikaripura taluk (3.01\%). In Shimoga, Hosanagar and Sagar taluk tannin contents were only $2.19,2.85$ and $2.99 \%$. The results of tannin content in different hoblies are presented in table 2.

The hobliwise variabilities in tannin contents of Shimoga districts were highly significant and it varied from 1.6 to $3.86 \%$. In most of the hoblies of Shimoga district tannin content was found to be in the range of $3 \%$. The less content was observed in Aynur and Nidige hoblies. Similarly, significant variations in tannin contents were noticed in Chikmagalur, Davangere, Chitradurga, Dakshina Kannada and Udupi districts. In Chikkamagalur district highest concentration of tannin was found in Ambale hobli $4.61 \%$ and then followed by
Vatahare hobli 4.18\%, Kasaba hobli of Kadur district. Less concentration was observed in Panchanahalli hobli $1.95 \%$.

In Davangere district, high concentration of tannin was found in Channagiri $2.13 \%$ followed by Jaglur $2.11 \%$, Honnali $1.90 \%$. Less content was observed in Davangere $1.28 \%$ and Harihara taluk $1.78 \%$. Among hoblies, highest concentration of tannin was found in Santhebennuru followed by Govinakovi hobli (2.68\%), the least content was in Anagodu hobli $0.62 \%$. In Chitradurga district, $3.25 \%$ of tannin was found in Hosadurga taluk followed by Hiriyur $2.41 \%$, Holalkere 2.35\% and Chitradurga 2.12\%. Tannin content varied among different hoblies of Chitradurga district. The high concentration was observed in Madadakere hobli $4.40 \%$ followed by Kasaba hobli of Holalkere taluk $3.22 \%$ and kasaba hobli of Hiriyur taluk $3.18 \%$. Less amount was found in Beedurga $(1.18 \%)$ and Ramagiri (1.46\%) hoblies. The tannin content was highest in Mudabidre taluk $2.46 \%$ followed by Puttur 2.25\%, Sullia $2.18 \%$ and Manglore $1.90 \%$ in D.K district. The less concentration was found in Bantwala $(1.13 \%)$ followed by Kadaba $(1.49 \%)$ and Belthagadi $(1.52 \%)$. With respect to hoblies tannin content was highest in Mudabidre hobli (2.46\%) was less in Vitla $(0.97 \%)$ and Bantwala (1.28\%) hoblies. Similarly in Udupi district, Baindur and udupi contained more tannin $2.18 \%$ and $2.07 \%$. The less content was observed in Kundapura 1.13\%, Karkala 1.94\% and Brahmavara 1.98\%. In Udupi district more concentration of tannin was found in Bainduru (2.16\%), Kapu (2.11\%) and Brahmavara (2.08\%) hoblies. While it was lower in Kundapura hobli (1.14\%).

Similarly, Kiran Kumar Rathod et.al (2015) have reported that arecanut wastes contain 50$60 \%$ of tannin and they act as precipitants of gelatins, alkaloids, glycosides, Heavy metals and proteins. 
Table.1 Talukwise variability in tannin contents (\%) of areca nut samples in different districts of Karnataka

\begin{tabular}{|c|c|c|c|c|c|c|}
\hline Districts & Shimoga & Chikkamagalur & Davanagere & Chitradurga & DK & Udupi \\
\hline 1. & $\begin{array}{c}2.19 \\
\text { (Shimoga) }\end{array}$ & $\begin{array}{c}3.39 \\
\text { (Chikamagalur) }\end{array}$ & $\begin{array}{c}2.13 \\
\text { (Channagiri) }\end{array}$ & $\begin{array}{c}2.12 \\
\text { (Chitradurga) }\end{array}$ & $\begin{array}{c}1.13 \\
\text { (Bantwala) }\end{array}$ & $\begin{array}{c}1.98 \\
\text { (Brahmavara) }\end{array}$ \\
\hline 2. & $\begin{array}{c}3.04 \\
\text { (Bhadravathi) }\end{array}$ & $\begin{array}{c}1.77 \\
\text { (Kadur) }\end{array}$ & $\begin{array}{c}1.28 \\
\text { (Davanagere) }\end{array}$ & $\begin{array}{c}2.41 \\
\text { (Hiriyur) }\end{array}$ & $\begin{array}{c}1.52 \\
\text { (Belthagadi) }\end{array}$ & $\begin{array}{c}2.18 \\
\text { (Baindur) }\end{array}$ \\
\hline 3. & $\begin{array}{c}2.99 \\
\text { (sagara) }\end{array}$ & $\begin{array}{c}3.33 \\
\text { (Корpa) }\end{array}$ & $\begin{array}{c}1.78 \\
\text { (Harihara) }\end{array}$ & $\begin{array}{c}2.35 \\
\text { (Holalkere) }\end{array}$ & $\begin{array}{c}1.49 \\
\text { (Kadaba) }\end{array}$ & $\begin{array}{c}1.94 \\
\text { (Karkala) }\end{array}$ \\
\hline 4. & $\begin{array}{c}2.85 \\
\text { (Hosanagar) }\end{array}$ & $\begin{array}{c}2.46 \\
\text { (Sringeri) }\end{array}$ & $\begin{array}{c}1.90 \\
\text { (Honnali) }\end{array}$ & $\begin{array}{c}3.25 \\
\text { (Hosadurga) }\end{array}$ & $\begin{array}{c}1.90 \\
\text { (Manglore) }\end{array}$ & $\begin{array}{c}1.13 \\
\text { (Kundapura) }\end{array}$ \\
\hline 5. & $\begin{array}{c}3.23 \\
\text { (Thirthahalli) }\end{array}$ & $\begin{array}{c}1.60 \\
\text { (Mudigere) }\end{array}$ & $\begin{array}{c}2.11 \\
\text { (Jagalur) }\end{array}$ & - & $\begin{array}{c}2.46 \\
\text { (Mudabidre) }\end{array}$ & $\begin{array}{c}2.07 \\
\text { (Udupi) }\end{array}$ \\
\hline 6. & $\begin{array}{c}3.15 \\
\text { (soraba) }\end{array}$ & $\begin{array}{c}3.33 \\
\text { (N R Pura) }\end{array}$ & - & - & $\begin{array}{c}2.25 \\
\text { (Puttur) }\end{array}$ & - \\
\hline 7. & $\begin{array}{c}3.01 \\
\text { (Shikaripura) }\end{array}$ & $\begin{array}{c}2.62 \\
\text { (Tarikere) }\end{array}$ & - & - & $\begin{array}{c}2.18 \\
\text { (Sullia) }\end{array}$ & - \\
\hline P 0.01 & $0.25 * *$ & $0.30 * *$ & $0.20 * *$ & $0.21 * *$ & $0.16^{* *}$ & $0.14 * *$ \\
\hline CV (\%) & 6.0995139 & 8.563846 & 8.019227 & 6.104986 & 6.500871 & 5.706501 \\
\hline S.Em \pm & 0.0797371 & 0.101207 & 0.066045 & 0.069116 & 0.053735 & 0.047396 \\
\hline
\end{tabular}

Table.3 Talukwise variability in Fiber contents (\%) of areca nut samples in different districts of Karnataka

\begin{tabular}{|c|c|c|c|c|c|c|}
\hline Districts & Shimoga & Chikkamagalur & Davanagere & Chitradurga & DK & Udupi \\
\hline 1. & $\begin{array}{l}43.49 \\
\text { (Shimoga) }\end{array}$ & $\begin{array}{l}40.03 \\
\text { (Chikkamagalur) }\end{array}$ & $\begin{array}{l}48.91 \\
\text { (Chennagiri) }\end{array}$ & $\begin{array}{l}54.34 \\
\text { (Chitradurga) }\end{array}$ & $\begin{array}{l}43.67 \\
\text { (Bantwala) }\end{array}$ & $\begin{array}{l}68.47 \\
\text { (Brahmavara) }\end{array}$ \\
\hline 2. & $\begin{array}{l}36.33 \\
\text { (Bhadravathi) }\end{array}$ & $\begin{array}{l}41.09 \\
\text { (Kadur) }\end{array}$ & $\begin{array}{l}49.16 \\
\text { (Davanagere) }\end{array}$ & $\begin{array}{l}58.96 \\
\text { (Hiriyur) }\end{array}$ & $\begin{array}{l}62.60 \\
\text { (Belthangadi) }\end{array}$ & $\begin{array}{l}72.87 \\
\text { (Baindur) }\end{array}$ \\
\hline 3. & $\begin{array}{l}65.22 \\
\text { (Sagar) }\end{array}$ & $\begin{array}{l}44.00 \\
\text { (Корpa) }\end{array}$ & $\begin{array}{l}52.80 \\
\text { (Harihara) }\end{array}$ & $\begin{array}{l}56.96 \\
\text { (Holalkere) }\end{array}$ & $\begin{array}{l}45.94 \\
\text { (Kadaba) }\end{array}$ & $\begin{array}{l}63.86 \\
\text { (Karkala) }\end{array}$ \\
\hline 4. & $\begin{array}{l}62.36 \\
\text { (Hosanagar) }\end{array}$ & $\begin{array}{l}44.39 \\
\text { (Sringeri) }\end{array}$ & $\begin{array}{l}41.89 \\
\text { (Honnali) }\end{array}$ & $\begin{array}{l}54.28 \\
\text { (Hosadurga) }\end{array}$ & $\begin{array}{l}61.82 \\
\text { (Mangaluru) }\end{array}$ & $\begin{array}{l}65.35 \\
\text { (Kundapura) }\end{array}$ \\
\hline 5. & $\begin{array}{l}41.07 \\
\text { (Thirthahalli) }\end{array}$ & $\begin{array}{l}28.02 \\
\text { (Mudigere) }\end{array}$ & $\begin{array}{l}52.78 \\
\text { (Jagalur) }\end{array}$ & - & $\begin{array}{l}41.63 \\
\text { (Mudabidre) }\end{array}$ & $\begin{array}{l}72.07 \\
\text { (Udupi) }\end{array}$ \\
\hline 6. & $\begin{array}{l}55.63 \\
(\text { Sorab) }\end{array}$ & $\begin{array}{l}56.19 \\
\text { (N R Pura) }\end{array}$ & - & - & $\begin{array}{l}41.51 \\
\text { (Puttur) }\end{array}$ & - \\
\hline 7. & $\begin{array}{l}40.24 \\
\text { (Shikaripura) }\end{array}$ & $\begin{array}{l}57.51 \\
\text { (Tarikere) }\end{array}$ & - & - & $\begin{array}{l}61.90 \\
\text { (Sullia) }\end{array}$ & - \\
\hline P 0.01 & $0.68 * *$ & $1.48 * *$ & $0.70 * *$ & $0.55 * *$ & $1.09 * *$ & $1.00 * *$ \\
\hline CV (\%) & 1.05 & 2.52 & 1.12 & 0.83 & 1.63 & 1.13 \\
\hline S.Em & 0.23 & 0.50 & 0.24 & 0.20 & 0.37 & 0.34 \\
\hline
\end{tabular}

(Name of taluks are in parenthesis) 
Table.2 Hobliwise variability in tannin contents (\%) in areca nut samples of different hoblies of Karnataka

\begin{tabular}{|c|c|c|c|c|c|c|}
\hline Districts & Shimoga & Chikkamagalur & Davanagere & Chitradurga & DK & Udupi \\
\hline \multicolumn{7}{|l|}{ Hoblies } \\
\hline 1. & 2.79 (Nidige) & 4.61 (Ambale) & 2.55 (Ubrani) & 2.01 (Talya) & 1.91 (Panemangalore) & 1.99 (Kota) \\
\hline 2. & 1.60 (Aynur) & 3.00 (Alduru) & 2.28 (Kasaba) & 2.49 (Turuvanooru) & 1.28 (Bantwala) & 2.08 (Brahmavara) \\
\hline 3. & 2.57 (Kumsi) & 2.13 (Avathi) & 1.15 (Basavapatna) & 2.62 (Talaku) & 0.97 (Vitla) & 2.16 (Baindur) \\
\hline 4. & 2.16 (Haranahalli) & 3.56 (Kasaba) & 1.42 (Santhebennur) & 2.01 (Bharamasagara) & 1.65 (Kokkada) & 1.93 (Ajekaru) \\
\hline 5. & 2.16 (Holalur) & 4.18 (Khandya) & 2.83 (Kasaba) & 2.43 (Nayakanahalli) & 1.67 (Belthangadi) & 2.16 (Karkala) \\
\hline 6. & 3.84 (Kasaba) & 3.82 (Yagati) & 0.62 (Anagodu) & 3.18 (Kasaba) & 1.29 (Venuru) & 1.14 (Kundapura) \\
\hline 7. & 3.60 (Kudlugere) & 3.69 (Hirenalluru) & 1.56 (Saswehalli) & 3.22 (Kasaba) & 2.28 (Kadaba) & 2.03 (Vadse) \\
\hline 8. & 1.74 (Holehonnur) & 2.25 (Panchanahalli) & 1.85 (Kasaba) & 1.46 (Ramagiri) & 2.15 (Gurupura) & $2.11(\mathrm{Kapu})$ \\
\hline 9. & 3.27 (Talaguppa) & 1.95 (Birur) & 1.11 (Mayagonda) & 3.12 (Parashurampura) & 2.46 (Mudabidre) & - \\
\hline 10. & 3.01 (Banagi) & 2.22 (Chaulahiriyur) & 2.62 (Bilichodu) & 1.18 (Beedurga) & 2.36 (Sullia) & - \\
\hline 11. & 2.48 (Anandapura) & 3.23 (Singatagere) & 1.75 (Arasikere) & 2.13 (Hiregunturu) & 1.87 (Panja) & - \\
\hline 12. & 3.86 (Avinahalli) & 2.73 (Kasaba) & 2.68 (Govinakovi) & 4.40 (Madadakere) & 2.36 (Puttur) & - \\
\hline 13. & 3.08 (Karooru) & 3.27 (Sakharayapattana) & 1.37 (Kasaba) & - & - & - \\
\hline 14. & 2.58 (Nagara) & 3.62 (Megunda) & 2.30 (Chigateri) & - & - & - \\
\hline 15. & 3.16 (Kerehalli) & 3.24 (Hariharapura) & 2.17 (Telagi) & - & - & - \\
\hline 16. & 3.26 (Huncha) & 2.95 (Kasaba) & 1.52 (Kasaba) & - & - & - \\
\hline 17. & 2.87 (Agumbe) & 2.08 (Kalasa) & 1.65 (Belagutthi) & - & - & - \\
\hline$\overline{18 .}$ & 3.28 (Muthuru) & 3.43 (Kasaba) & 2.62 (Malebennur) & - & - & - \\
\hline 19. & 3.28 (Mandagadde) & 2.62 (Kigga) & - & - & - & - \\
\hline 20. & 2.91 (Agrahara) & 2.28 (Gonibidu) & - & - & - & - \\
\hline 21. & 2.79 (Kuppagadde) & 3.23 (N R Pura) & - & - & - & - \\
\hline 22. & 2.96 (uluri) & 3.57 (Balooru) & - & - & - & - \\
\hline 23. & 3.23 (Chandragutti) & 2.65 (Kasaba) & - & - & - & - \\
\hline 24. & 3.71 (Jade) & 2.95(Lakya) & - & - & - & - \\
\hline 25. & 3.49 (Udugani) & - & - & - & - & - \\
\hline 26. & 2.81 (Kasaba) & - & - & - & - & - \\
\hline 27. & 2.80 (Kasaba) & - & - & - & - & - \\
\hline 28. & 3.85 (Hosuru) & - & - & - & - & - \\
\hline 29. & 3.17 (Anjanapura) & - & - & - & - & - \\
\hline 30. & 3.58 (Anwatti) & - & - & - & - & - \\
\hline 31. & 3.66 (Bhadravathi) & - & - & - & - & - \\
\hline 32. & 1.89 (Anaveri) & - & - & - & - & - \\
\hline 33. & 2.89 (Kallihal) & - & - & - & - & - \\
\hline 34. & 3.20 (Shiralkoppa) & - & - & - & - & - \\
\hline 35. & 3.32 (Kasaba) & - & - & - & - & - \\
\hline 36. & 3.04 (Shikaripura) & - & - & - & - & - \\
\hline 37. & 3.32 (Kasaba) & & & & & \\
\hline P 0.01 & $0.20 * *$ & $0.14 * *$ & $0.13 * *$ & $0.21^{* *}$ & $0.05^{* *}$ & $0.11^{* *}$ \\
\hline CV (\%) & 4.073794831 & 3.090234 & 5.332046 & 5.590033 & 1.874382 & 3.532902 \\
\hline S.Em \pm & 0.070693689 & 0.054459 & 0.058251 & 0.081349 & 0.020092 & 0.039809 \\
\hline
\end{tabular}

(Name of taluks are in parenthesis) 
Table.4 Hobliwise variability in Fiber contents $(\%)$ in areca nut samples of different hoblies of Karnataka

\begin{tabular}{|c|c|c|c|c|c|c|}
\hline $\begin{array}{c}\text { Districts } \\
\text { Hoblies } \\
\end{array}$ & Shimoga & Chikkamagalur & Davanagere & Chitradurga & DK & Udupi \\
\hline 1. & 40.96 (Nidige) & 46.29 (Ambale) & 57.34 (Ubrani) & 58.09 (Talya) & 50.74 (Panemangalore) & 72.23 (Kota) \\
\hline 2. & 39.69 (Aynur) & 33.14 (Alduru) & 46.73 (Kasaba) & 47.23 (Turuvanoor) & 38.97 (Bantwala) & 64.26 (Brahmavara) \\
\hline 3. & 25.93 (Kumsi) & 30.14 (Avathi) & 46.44 (Basavapatna) & 52.31 (Talaku) & 41.10 (Vitla) & 72.41 (Baindur) \\
\hline 4. & 35.95 (Haranahalli) & 26.45 (Kasaba) & 59.25 (Santhebennur) & 59.62 (Bharamasagara) & 46.02 (Kokkada) & 66.41 (Ajekaru) \\
\hline 5. & 53.52 (Holalur) & 40.24 (Khandya) & 44.40 (Kasaba) & 59.23(Nayakanahalli) & 45.47 (Belthangadi) & 69.52 (Karkala) \\
\hline 6. & 51.57 (Kasaba) & 58.46 (Yagati) & 37.36 (Anagodu) & 65.33 (Kasaba) & 78.83 (Venuru) & 63.91 (Kundapura) \\
\hline 7. & 48.93 (Kudlugere) & 38.34 (Hirenallur) & 47.74 (Saswehalli) & 50.86 (Kasaba) & 62.63 (Kadaba) & 67.54 (Vadse) \\
\hline 8. & 43.73 (Holehonnur) & 44.06 (Panchanahalli) & 56.59 (Kasaba) & 65.05 (Ramagiri) & 73.15 (Gurupura) & 65.38 (Kapu) \\
\hline 9. & 51.15 (Talaguppa) & 45.45 (Birur) & 43.47(Mayagonda) & 54.66 (Parashurampura) & 54.84 (Mudabidre) & 77.59 (Kasaba) \\
\hline 10. & 27.21 (Banagi) & 24.43 (Chaulahiriyur) & 53.39 (Bilichodu) & 62.76 (Beedurga) & 55.14 (Sullia) & - \\
\hline 11. & 32.95 (Anandapura) & 42.16 (Singatagere) & 50.68 (Arasikere) & 45.76 (Madadakere) & 77.49 (Panja) & - \\
\hline 12. & 49.96 (Avinahalli) & 20.46 (Kasaba) & 20.39(Govinkovi) & - & 39.16 (Puttur) & - \\
\hline 13. & 35.53 (Karooru) & 59.76 (Sakharayapattana) & 31.95 (Kasaba) & - & 51.74 (Mangalore) & - \\
\hline 14. & 51.22 (Nagara) & 45.54 (Megunda) & 38.39 (Chigateri) & - & 41.92 (Uppinangadi) & - \\
\hline 15. & 58.18 (Kerehalli) & 41.24 (Hariharapura) & 52.75 (Telagi) & - & 44.04 (Kasaba) & - \\
\hline 16. & 62.44 (Huncha) & 61.50 (Kasaba) & 58.33 (Kasaba) & - & - & - \\
\hline 17. & 82.15 (Agumbe) & 46.68 (Kalasa) & 49.23 (Belagutti) & - & - & - \\
\hline 18. & 71.92 (muthuru) & 42.90 (Kasaba) & 55.60 (Malebennur) & - & - & - \\
\hline 19. & 57.19 (Mandagadde) & 32.13 (Kigga) & 49.20 (Kasaba) & - & - & - \\
\hline 20. & 81.87 (Agrahara) & 25.15 (Gonibidu) & - & - & - & - \\
\hline 21. & 58.93 (Kuppagadde) & 54.94 (N R Pura) & - & - & - & - \\
\hline 22. & 51.22 (Uluri) & 59.70 (Balooru) & - & - & - & - \\
\hline 23. & 18.56 (Chandragutti) & 47.68 (Kasaba) & - & - & - & - \\
\hline 24. & 58.26 (Jade) & 52.29 (Lakya) & - & - & - & - \\
\hline 25. & 46.49 (Udugani) & 46.29 (Balehonnur) & - & - & - & - \\
\hline 26. & 40.52 (Kasaba) & 33.14 (Ajjampura) & - & - & - & - \\
\hline 27. & 58.71 (Kasaba) & - & - & - & - & - \\
\hline 28. & 61.74 (Hosuru) & - & - & - & - & - \\
\hline 29. & 54.44 (Anjanapura) & - & - & - & - & - \\
\hline 30. & 58.32 (Anwatti) & - & - & - & - & - \\
\hline 31. & 41.83 (Bhadravathi) & - & - & - & - & - \\
\hline 32. & 59.79 (Anaveri) & - & - & - & - & - \\
\hline 33. & 43.37 (Kallihal) & - & - & - & - & - \\
\hline 34. & 47.97 (Shiralkoppa) & - & - & - & - & - \\
\hline 35. & 30.79 (Kasaba) & - & - & - & - & - \\
\hline 36. & 53.42 (Shikaripura) & - & - & - & - & - \\
\hline 37. & 22.61 (Kasaba) & - & - & - & - & - \\
\hline CV (\%) & 1.724 & 1.86523 & 1.892084 & 1.125744 & 0.741475 & 0.55066 \\
\hline S.Em \pm & 0.486 & 0.457291 & 0.517006 & 0.366866 & 0.228666 & 0.218753 \\
\hline P 0.01 & $1.2 * *$ & $1.30^{* *}$ & $1.50 * *$ & $1.07 * *$ & $0.65^{* *}$ & NS \\
\hline
\end{tabular}

(Name of hoblies are in parenthesis) 


\section{Fiber content $(\%)$ in areca nut}

The experimental values obtained for fiber in different areca growing areas of Karnataka are presented in Table 3 and 4 . The fiber content varied among districts, hoblies and taluks. In Shimoga district high fiber content was estimated in Anandpura hobli $(82.15 \%)$ of Sagara taluk followed by Kerehalli hobli $(81.87 \%)$ of Hosanagara taluk and very less amount was estimated in Mandagadde hobli $(18.56 \%)$ of Thirthahalli taluk.

There was a significant difference between the fiber content in different hoblies of Chikkamagalur district. High fiber content was determined in Kasaba hobli $(61.50 \%)$ of Narasimharajapura taluk and it was comparatively less in Kasaba hobli (20.46\%) of Kadur taluk. Less amount of fiber was observed in Govinakovi hobli $(20.39 \%)$ of Davanagere district and it was estimated high in Santhebennuru hobli $(59.25 \%)$ of Channagiri taluk, Davanagere district. The Kasaba hobli $(65.33 \%)$ of Chitradurga taluk and Ramagiri hobli (65.05\%) of Holalkere taluk had highest fiber content and less content was in Madadakere hobli $(45.76 \%)$ of Hosadurga taluk. Significantly high amount of fiber was estimated in Venuru hobli (78.83\%) of Belthangadi taluk followed by Panja hobli (77.49\%) of Sullia taluk and it was less in Bantwala hobli (38.97 \%) of Bantwala taluk. There was no significant difference in fiber content in Udupi district. The content of fiber varied between $63.9 \%$ and $77.5 \%$.

In Shimoga district Sagara and Hosanagara taluk had high fiber content (65.22 and 62.36 $\%)$ and less was in Bhadravathi taluk (36.33 $\%$ ). In Tarikere and N R Pura taluks of Chikkamagalur district, high amount of fiber were determined (57.51 and $56.19 \%)$ and it was less in Mudigere taluk (28.02 \%). In Harihara and Jagalur taluk of Davanagere district. The fiber contents were 52.80 and $52.78 \%$ respectively. There was no significant difference in fiber content in Chitradurga district. In Dakshina kannada district, less amount of fiber was observed in Puttur $(41.51 \%)$ and Bantwala taluks (43.67 $\%)$ and high was observed in Belthangadi $(62.62 \%)$ and Sullia (61.90 \%) taluks. Jayalakhsmi et al., (1982) have reported that the crude fiber content in areca varied from 7.1 to 17.4 percent in chali type of nuts.

Tannins are gaining importance in human diet for their anti-oxidating properties. It is because of accumulation of $\mathrm{OH}$ group on small size nucleus, these agents have oxidative nature. Estimation of tannin in areca nut was carried out by titrating with standard potassium permanganate solution. Results of the tannin content in different district of areca nut sample were found to vary significantly. The contents of tannin in areca nut samples varied from 1.13 to $3.39 \%$ in different districts of Karnataka.

Fiber impart hardness to mature areca nut which is highly essential for preparation of processed quality areca nut. The immature nuts contain less fiber (1-2\%) and it increases with maturity. The areca samples collected from different districts of Karnataka significantly varied in their fiber content except the samples of Udupi district. The contents of fiber ranged from $28-72 \%$ at mature stage suitable for wet process. The variability in tannin and fiber contents may be due to difference in varieties, agronomic practices processing technique, climate, water stress, and soil texture.

\section{References}

Atanassova, M., Christova-Bagdassaria, V. 2009. Determination of tannins content by titrimetric method for comparison of different plant species. Journal of the 
University of Chemical Technology and Metallurgy, 44, (4): 413-41.

Kiran Kumar Rathod, M, Shivaprsad, M., Rajashekar, 2015. Characterization and extraction of tannin from arecanut waste and using it as rust deactivator. International journal of science, Engineering and Technology, 3(2): 366372.

Mohan kumar, G.C. 2002. Natural Areca Fibers and their Composites, Workshop on Natural Fiber composites. Indian Institute of Technology Madras, Chennai, India.

Ramachandra Reddy, G., Ashok Kumar, M., Chakradhar K. V. P. 2011. Fabrication and performance of hybrid betel nut (Areca Catechu) short fiber/Sansevieria cylindrical (Agavaceae) epoxy composites. International journal of Materials and Biomaterials Applications, 1(1):6-13.

\section{How to cite this article:}

Gurumurthy, B.R. 2018. Diversity in Tannin and Fiber Content in Areca Nut (Areca catechu) Samples of Karnataka, India. Int.J.Curr.Microbiol.App.Sci. 7(01): 2899-2906.

doi: https://doi.org/10.20546/ijcmas.2018.701.346 